\title{
Investigating Malaysian teachers' technology acceptance towards integrating e-learning into English teaching
}

\author{
Ke Hu ${ }^{1}$, Asmaa AlSaqqaf 2* \\ ${ }^{1}$ School of International Business, Hunan University of Information Technology, China \\ kingsleywuwu@gmail.com \\ 2 Faculty of Psychology and Education, Universiti Malaysia Sabah (UMS), Malaysia \\ *asma3030@yahoo.com (Corresponding Author)
}

DOI: http://dx.doi.org/10.26418/jeltim.v3i2.46798

\begin{abstract}
The presence of e-learning is prevalent in the teaching and learning process over the world. It has been proven to have a significant impact on the teaching of English subject. Therefore, this paper aims at investigating the level of ESL teachers' technology acceptance towards integrating e-learning into English teaching at secondary schools in Sabah, Malaysia, by examining the constructs of Perceived Usefulness (PE), Perceived Ease of Use (PEOU), Attitude towards Usage (ATU), and Behavioral Intention (BI), which were extracted from the Technology Acceptance Model (TAM) proposed by Davis. A number of 144 English language teachers from 18 secondary schools in Kota Kinabalu responded to an online cross-sectional survey based on a simple random sampling, whereas the collected data were analyzed quantitatively and statistically. Overall, the results indicated that ESL teachers had a high level of technology acceptance (mean=3.921) to use e-learning in teaching English in terms of their PU (mean=3.925), PEOU (mean=3.797), ATU (mean=4.007), and BI (mean=3.995) in particular. Moreover, the discussions, recommendations, and implications have also been given in response to the issues addressed in the study.
\end{abstract}

Keywords: technology acceptance; e-learning; ESL teachers; secondary education; Sabah

How to cite this paper: Hu, K. \& AlSaqqaf, A. (2021). Investigating Malaysian teachers' technology acceptance towards integrating e-learning into English teaching. Journal of English Language Teaching Innovations and Materials (Jeltim), 3(2), 87-98. DOI: http://dx.doi.org/10.26418/jeltim.v3i2.46798 
To link to this article: http:/ / dx.doi.org/10.26418/jeltim.v3i2.46798

This work is licensed under a Creative Commons Attribution

NonCommercial-ShareAlike 4.0 International License.

Nowadays, the use of e-learning is perceived as an evitable trend in education. It has offered the related educational stakeholders with various means to enhance the quality of teaching and learning through the usage of the Internet, multimedia, as well as ICTs, etc (Trayek, et al., 2016). Therefore, the Malaysian Ministry of Education (MoE) has paid close attention to use e-learning as a part of the teaching and learning process by documenting it in its Education Blueprint (2013-2025). This official measure intends to accelerate the progress of the Fourth Industrial Revolution (IR 4.0) in education in Malaysia (Shahroom \& Hussin, 2018).

Based on Clarke (2008), the use of e-learning has brought about several changes to language teaching and learning since it has also boosted the new pedagogical methods to language teachers. As far as it is concerned, English language teachers and students are convenient to get viable information and materials, and self-regulation is also cultivated by students when integrating elearning into English teaching (Ng \& Confessore, 2011; Cai, 2012). Even the idea of using e-learning in teaching has emerged for decades since the last century, however, it is still disputable and debatable among developing countries, such as Malaysia. As reported by Hew and Sharifah Latifah Syed Abdul Kadirb (2016), the majority of school teachers from Malaysian public schools are not fully immersed in utilizing e-learning in enhancing their teaching professions as required by its $\mathrm{MoE}$ (Hu, AlSaqqaf \& Swanto, 2020). Therefore, there is a necessity to investigate ESL teachers' perceptions of their technology acceptance (Hu, AlSaqqaf \& Swanto, 2020). A comprehensive model named Technology Acceptance Model (TAM) was employed as the theoretical support for the study. In this study, four related constructs (e.g. Perceived Usefulness (PU), Perceived Ease of Use (PEOU), Attitude towards Usage (ATU), and Behavioral Intention (BI) proposed by Davis (1989) in TAM were employed to investigate secondary school ESL teachers' level of technology acceptance to use e-learning in teaching. It tried to deepen the understanding of TAM with secondary school ESL teachers in the context of Sabah. Besides that, it comes along with a research question as follows:

What are the secondary school ESL teachers' level of PE, PEOU, ATU, and BI towards integrating e-learning into English teaching in the context of Sabah?

Implicationally, this study also intended to extend the existing literature of TAM by incorporating the perceptions of secondary school ESL teachers from Sabah, Malaysia. And then, it is useful to review the effectiveness of current 
policies related to e-learning launched by the government on a national scale. Moreover, it is also hoped to pay more attention to Sabah, where Sabah is always being neglected when compared to other states in Malaysia.

\section{LITERATURE REVIEW}

\section{ICT Infrastructure in Malaysia}

In the early of 1970s, the importance of using information and communication technology (ICT) in the teaching and learning process has been noticed by the Malaysian government. Since that, Malaysia has gone on with the vision and kept exploring the most proper ways to enhance the quality of education and improve its competition capacity to face globalization (Rosyidah Muhammad, 2015). However, based on the report revealed in Sabah's State ICT Blueprint (Ministry of Resource Development and IT, 2011), Sabah was in trouble with its Internet coverage, ICT infrastructure, and the inadequate ownership of personal electronic devices when compared to other states.

\section{The Importance of E-learning Usage in English Teaching and Learning}

The use of e-learning in teaching is regarded as a new trend among English language teachers at schools. As concluded by Malaysian English Language Education Reform Roadmap 2015-2025 (English Language Standards and Quality Council, 2015), it is helpful to make students form their higher order thinking skills (HOTs) and $21^{\text {st }}$ century skills while learning the English language through the use of ICT. It has been proven by Ling and Muuk (2015), and Imtiaz Hassan Taj, et al., (2017), students' attention could be easily focused on and their vocabularies were enhanced gradually while they exposed to e-learning.

\section{Technology Acceptance Model (TAM)}

TAM was initially proposed by Davis (1989) (refers to Figure 1), which intended to illustrate how related stakeholders to adapt themselves to accept the

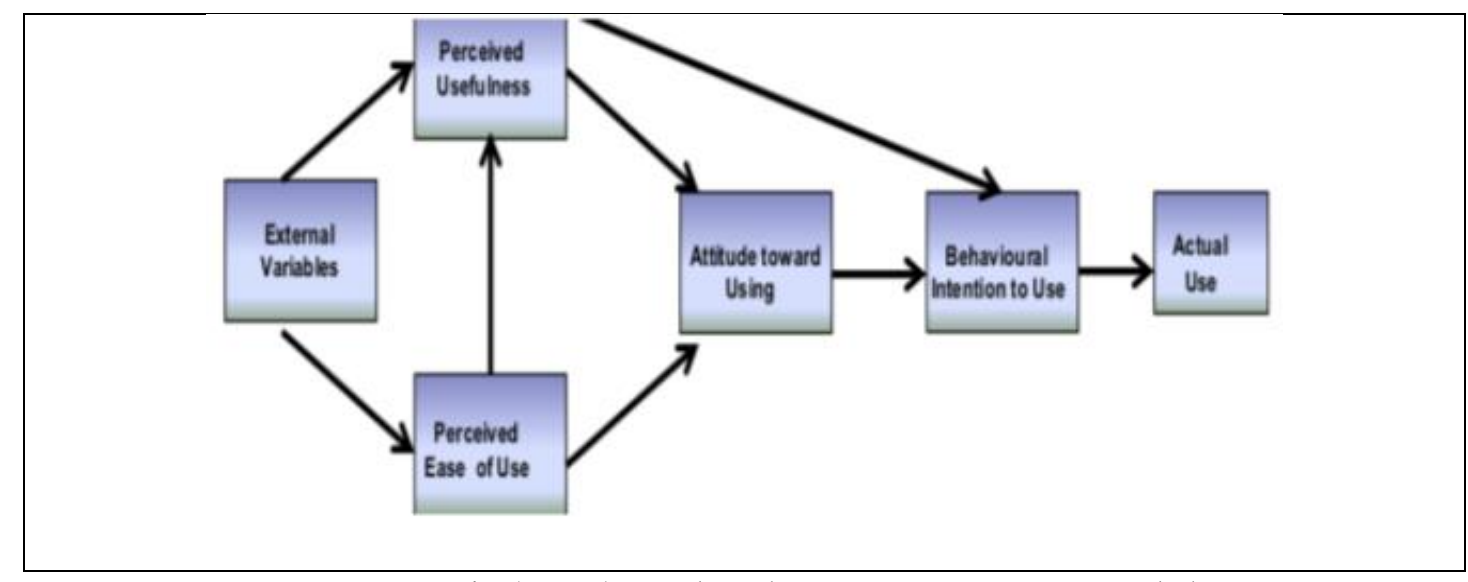

Figure 1. Davis's (1989) Technology Acceptance Model 
use of e-learning. These constructs namely PU, PEOU, ATU, and BI are vitally used in the model to predict technology acceptance. According to Davis (1989), PE is defined as ones' belief towards using e-learning that would or not improve their performance in work, while PEOU is given that the use of e-learning is easier than other methods. Besides that, ATU is affected by PU and PEOU, and BIU refers to ones' intention to perform a given behavior willingly. Based on the study conducted by Kwok and Yong (2017), and Mohammed Simko Abdullah and Mehmet Toycan (2018), individuals with a high value of PEOU would result in positive attitudes and behavioral intention towards using e-learning.

\section{METHODS}

This study was constructed on the basis of positivism, which holds the scientific stance for the nature of the study (Mack, 2010). It resulted in a quantitative-based study, and then a cross-sectional survey was also deployed to collect the data from target participants which were randomly sampled from the population. Therefore, the data of the study were collected by the scientific method and analyzed statistically, and the findings of the study could be generalized to others.

To assure the adequacy of participant involvement and draw the generalization to this particular phenomenon investigated. A sampling table proposed by Krejcie and Morgan (1970) was used for sampling purpose, whereas in align with the research context, it required to randomly select at least 123 secondary school ESL teachers from a total number of 179 particularly.

After that, the use of questionnaires was employed in the study to collect the data. The questionnaire was comprised of 15 closed-ended questions in the form of a 5-point Likert Scale (1: Strongly Disagree, 2: Disagree, 3: Neutral, 4: Agree, and 5: Strongly Agree), which were adapted from the previous literature. Prior to the actual administration of the questionnaire, it had been undergone several rigorous measures, such as content validity and face validity with a few experts from university and secondary school respectively. And also, the results of the pilot study were found reliable to account for the practicability of the questionnaire used for the actual study.

Table 1: Guideline for technology acceptance

\begin{tabular}{ll}
\hline Categories of level & Range of means \\
\hline Low & $1.0-2.4$ \\
\hline Medium & $2.5-3.4$ \\
\hline High & $3.5-5.0$ \\
\hline
\end{tabular}

Moreover, an indication of technology acceptance level was determined by its mean in accordance with the guideline proposed by Oxford and Burry-

Journal of English Language Teaching Innovations and Materials (Jeltim), 3(2), 87-198 Copyright (c) 2021 by the authors, e-ISSN 2657-1617 
Stock (1995). Three different levels are suggested as follows, the averages of 1.0 to 2.4 are considered as low level, the medium level is from 2.5 to 3.4 , and then the high level is ranged from 3.5 to 5.0 (Table 1 ).

\section{FINDINGS}

The results were derived from the descriptive analysis using SPSS 26, including frequency, percentages, means, and standard deviation.

\section{Demographics}

Table 2. Demographics of participants

\begin{tabular}{llll}
\hline & & frequency & Percent \\
\hline Gender & Male & 19 & 13.2 \\
& Female & 125 & 86.8 \\
& Total & 144 & 100 \\
\hline Age & $20-30$ years old & 3 & 2.1 \\
& $31-40$ years old & 47 & 32.6 \\
& 41 years old and 94 & 65.3 \\
& above & 144 & 100 \\
\hline Educational background & Total & & \\
& Graduate level & 114 & 79.2 \\
& Post-graduate level & 30 & 20.8 \\
& Total & 144 & 100 \\
\hline
\end{tabular}

As Table 2 indicated, the gender allocation of participants was uneven, the majority of participants were female ESL teachers (86\%), and only 19 male ESL teachers participated in the study. When itcomes to their ages, $65.3 \%$ of participants were aged 41 years and above, then it was followed by that of 31-40 years old and 20-30 years old with a percentage of 32.6 and 2.1 respectively. Besides that, $79.2 \%$ of participants were graduates while 20.8 of them were postgraduates.

\section{Reliability}

Table 3. Results of reliability

\begin{tabular}{ll}
\hline Constructs & Values of alpha $(>\mathbf{0 . 7 0})$ \\
\hline PU & 0.959 \\
\hline PEOU & 0.957 \\
\hline BI & 0.954 \\
\hline ATU & 0.940 \\
\hline
\end{tabular}

As Table 3 stated that these four constructs were reliable to be used in the study to assess ESL teachers' technology acceptance since the alpha values were all greater than the accepted level of 0.70 (Taber, 2018). 


\section{Level of Technology Acceptance}

Table 4. Descriptive analysis of participants' perceived usefulness

\begin{tabular}{ll|ll}
\hline No. & Perceived Usefulness (overall mean=3.925, $\mathbf{n = 1 4 4 )}$ & Mean & $\begin{array}{l}\text { Std. } \\
\text { Deviation }\end{array}$ \\
\hline 1 & $\begin{array}{l}\text { Using e-learning in teaching English would improve } \\
\text { my job performance. }\end{array}$ & 3.92 & 0.789 \\
\hline 2 & $\begin{array}{l}\text { Teaching English with the integration of e-learning } \\
\text { would increase my job productivity. }\end{array}$ & 3.91 & 0.836 \\
\hline $3 \quad \begin{array}{l}\text { Using e-learning would enhance my effectiveness on } \\
\text { the job. }\end{array}$ & 3.88 & 0.835 \\
\hline $4 \quad$ I would find e-learning useful in my job. & 3.99 & 0.828 \\
\hline $5 \quad$ & $\begin{array}{l}\text { Using e-learning would make my English teaching } \\
\text { easier. }\end{array}$ & 3.94 & 0.846 \\
\hline & The overall mean of perceived usefulness & $\mathbf{3 . 9 2 5}$ & $\mathbf{0 . 8 2 7}$ \\
\hline Oxford and Burry-Stock's guideline & High level \\
\hline
\end{tabular}

Data presented in Table 4 revealed that ESL teachers had a high level of perceived usefulness towards using e-learning $(m=3.925)$. They agreed that the use of e-learning is useful in their jobs $(\mathrm{m}=3.99)$, making the teaching of English easier $(\mathrm{m}=3.94)$, could also improve their job performance $(\mathrm{m}=3.92)$, productivity $(\mathrm{m}=3.91)$, and also effectiveness $(\mathrm{m}=3.88)$.

Table 5. Descriptive analysis of participants' perceived ease of use

\begin{tabular}{|c|c|c|c|}
\hline No. & $\begin{array}{l}\begin{array}{l}\text { Perceived Ease of Use (overall mean=3.797, } \\
n=144)\end{array}\end{array}$ & Mean & $\begin{array}{l}\text { Std. } \\
\text { Deviation }\end{array}$ \\
\hline 1 & $\begin{array}{l}\text { I would find it easy to get what I want to do when } \\
\text { I use e-learning in teaching English. }\end{array}$ & 3.84 & 0.825 \\
\hline 2 & $\begin{array}{l}\text { I would find e-learning to be flexible to interact } \\
\text { with. }\end{array}$ & 3.82 & 0.825 \\
\hline 3 & $\begin{array}{l}\text { My interaction with the use of e-learning would be } \\
\text { "clear and understandable". }\end{array}$ & 3.77 & 0.817 \\
\hline 4 & $\begin{array}{l}\text { It would be easy for me to become skillful at using } \\
\text { e-learning while teaching English. }\end{array}$ & 3.76 & 0.887 \\
\hline & The overall mean of perceived ease of use & 3.797 & 0.839 \\
\hline Oxfc & rd and Burry-Stock's guideline & \multicolumn{2}{|c|}{ High level } \\
\hline
\end{tabular}

As Table 5 presented, ESL teachers had a high level of perceived ease of use towards using e-learning $(\mathrm{m}=3.797)$. To be more exact, they affirmed that by 
using e-learning, their needs for teaching English could easily be fulfilled $(\mathrm{m}=3.84)$, it also brought good flexibility $(\mathrm{m}=3.82)$ and interactions $(\mathrm{m}=3.77)$, and their skills would also be boosted while using e-learning $(\mathrm{m}=3.76)$.

Table 6. Descriptive analysis of participants' behavioral intention

\begin{tabular}{ll|ll}
\hline No. & Behavioral Intention (overall mean=3.995, $\mathbf{n = 1 4 4 )}$ & Mean & $\begin{array}{l}\text { Std. } \\
\text { Deviation }\end{array}$ \\
\hline 1 & I plan to use e-learning in the future. & 4.00 & 0.766 \\
\hline 2 & I intend to use e-learning in the future. & 3.97 & 0.784 \\
\hline $3 \quad$ I predict I would use e-learning in the future. & 4.01 & 0.775 \\
\hline & The overall mean of behavioral intention & $\mathbf{3 . 9 9 5}$ & $\mathbf{0 . 7 7 5}$ \\
\hline Oxford and Burry-Stock's guideline & \multicolumn{2}{l}{ High level } \\
\hline
\end{tabular}

Results stated in Table 6 showed that ESL teachers had a high level of behavioral intention towards using e-learning $(\mathrm{m}=3.995)$. They expressed highly positive intention towards using e-learning in teaching English in the future.

Table 7. Descriptive analysis of participants' attitude towards usage

\begin{tabular}{|c|c|c|c|}
\hline No. & $\begin{array}{l}\text { Attitude towards Usage (overall mean=4.007, } \\
\mathrm{n}=144 \text { ) }\end{array}$ & Mean & $\begin{array}{l}\text { Std. } \\
\text { Deviation }\end{array}$ \\
\hline 1 & $\begin{array}{l}\text { I believe that it is a good idea to use e-learning in } \\
\text { teaching English. }\end{array}$ & 3.97 & 0.810 \\
\hline 2 & I like the idea of using e-learning in teaching English. & 3.99 & 0.789 \\
\hline 3 & Using e-learning in teaching is a positive idea. & 4.06 & 0.809 \\
\hline & The overall mean of attitude towards usage & 4.007 & 0.803 \\
\hline $\mathrm{Oxfc}$ & d and Burry-Stock's guideline & \multicolumn{2}{|c|}{ High level } \\
\hline
\end{tabular}

Based on Table 7, ESL teachers had a high level of attitude towards usage when asked to use e-learning in the teaching of English. They considered that it is either a positive or good idea to use e-learning in teaching $(\mathrm{m}=4.06, \mathrm{~m}=3.97)$ respectively, and they were fond of using e-learning $(\mathrm{m}=3.99)$.

\section{DISCUSSIONS}

The results were in line with the study conducted by Hendehjan and Noordin (2013), revealing that participants' level of perceived ease of use was at moderate to high, whereas their level of perceived usefulness was at a high level. It was also consistent with Soleimani, Ismail, and Mustaffa (2014), they found that participants involved in the study showed high levels of perceived ease of use and perceived usefulness, and behavioral intention. Moreover, in a study carried out by Ahmad Sobri Hashim, Wan Fatimah Wan Aamad, Aliza Sarlan 
(2017), these schools located in urban areas had a high level of technology acceptance concerning its perceived usefulness, perceived usefulness, attitude towards usage, and behavioral intention.

In contrast, based on the study conducted by Wong and Teo (2009), they found out respondents had a low level of technology acceptance in Malaysia. A few years later, a study conducted by Tan (2018) revealed that pre-service ESL teachers' technology acceptance was found at a moderate level in their perceived usefulness, perceived ease of use, and behavioral intention. Huang and Teo (2016) found that Chinese teachers had a low level of technology acceptance in teaching, and Kirmizi (2014) also found participants had a lower level of attitude towards using technology in teaching.

Here are several latent justifications stated as follows under this discussion. At first, these participants involved in the current study are working with secondary schools located in urban areas. They have quite a long experience of adapting themselves to use technology in teaching because they have been asked to participate in some professional training related to integrating elearning into teaching. Therefore, they are more familiar with the visions on the use of e-learning in teaching proposed by Malaysia's MoE. Apart from that, along with plenty of investments given by the government to deploy e-learning, the provisions and administration of e-learning at schools have been even more developed and advanced from time to time. Therefore, ESL teachers agree that the use of e-learning in teaching English is an evitable trend in education nowadays due to it could bring them useful information and materials into the teaching of English. On the other hand, ESL teachers advocate integrating elearning in English teaching because of its benefits, effectiveness, and usefulness.

These assumptions are supported by Kementerian Pendidikan Malaysia (2013), and Rubaai and Hashim (2019). They raised that ESL teachers value the usefulness and ease of use of e-learning in English language teaching and learning, thanks to plenty of investments and programs of e-learning has been launched and given by government such as ICTs-oriented training and infrastructural development to cultivate their initiative and acceptance to embrace the use of e-learning. That explains why these ESL teachers have such a positive perception of technology acceptance and results in a high level of technology acceptance generally.

\section{LIMITATIONS AND RECOMMENDATIONS}

Here are some limitations of the study. Above all, the study only employed ESL teachers from secondary schools located in urban areas in Sabah. Then, the perceptions of ESL teachers working in rural areas have no chances to be entertained and surveyed thanks to the obstacles, such as financial support,

Journal of English Language Teaching Innovations and Materials (Jeltim), 3(2), 87-198

Copyright (C) 2021 by the authors, e-ISSN 2657-1617 
time-constraints, transportation problems, and language barrier. Secondly, the uneven participant involvement in the study in terms of their genders. It is obvious to be seen that female ESL teachers $(86.8 \%)$ were the majority involved in the study when compared to male ESL teachers (13.2\%). Besides that, only descriptive analysis was used to analyze the collected data. Therefore, it is recommended and hoped that future studies may approach and recruit more ESL teachers from rural areas in Sabah, to generalize more various and comprehensive ESL teachers' perceptions of technology acceptance. And also, it is doable by changing the sampling method (e.g. purposive sampling) if the researchers want to make the involvement of participants' genders allocate evenly. Moreover, more analysis methods, such as inferential analysis could also be deployed in future studies but based on their particular needs.

\section{CONCLUSION}

The objective of the study was completed indicating the level of ESL teachers' technology acceptance to use e-learning by distributing the survey questionnaires to the sampled participants. The results revealed that ESL teachers achieved a high level of technology acceptance in the teaching of English in terms of PU, PEOU, BI, and ATU. Therefore, the findings of the study are vital to be referred to, since they have given newly insight into many stakeholders, such as policymakers, principals, and teachers to come up with and develop the policies for a better e-learning implementation to enhance the quality of teaching at schools.

\section{REFERENCES}

Ahmad Sobri Hashim,. Wan Fatimah Wan Ahmad., \& Aliza Sarlan. (2017). A study on acceptance of mobileschool at secondary schools in Malaysia: Urban vs rural. Retrieved from https://aip.scitation.org/doi/abs/10.1063/1.5005383

Cai, H. (2012). E-learning and English Teaching. IERI Procedia, 2, 841-846.

Clarke, A. (2008). E-learning skills. New York, NY: Palgrave Macmillan. Davis, F. D. (1989). Perceived usefulness, perceived ease of use, and user acceptance of information technology. MIS Quarterly, 13(3), 319-340.

English Language Standards and Quality Council. (2015). English Language Education Reform in Malaysia-The Roadmap 2015-2025. Retrieved from http:/ /eltc.moe.edu.my/roadmap/The\%20Roadmap\%202015-2025.pdf

Huang, F.,\& Teo, T. (2016). Technology acceptance among EFL teachers in China: applying the theory of planned behavior. Retrieved from 
https://www.worldresearchlibrary.org/up_proc/pdf/567148603911319- 23.pdf

Hendehjan, N. M., \& Noordin, N. (2013). Level of information \& communication technology (ICT) usage among ESL teachers in Malaysia. International Journal of Education and Literacy Studies, 1(1), 7-14.

Hew, T. S., \& Sharifah Latifah Syed Abdul Kadirb. (2016). Understanding cloudbased VLE from the SDT and CET perspectives: Development and validation of a measurement instrument. Computers $\mathcal{E}$ Education, 101(2016), 132-149.

Hu, K., AlSaqqaf, A. \& Swanto, S. (2020). E-learning readiness among English language teachers in Sabah, Malaysia: A pilot study. Journal of English Language Teaching Innovations and Materials (JELTIM), 2(2), 120-127. DOI: http://dx.doi.org/10.26418/jeltim.v1i1.42155

Imtiaz Hassan Taj., Fatimah Ali., Muhammad Aslam Sipra., \& Waqar Ahmad. (2017). Effect of technology enhanced language learning on vocabulary acquisition of EFL learners. International Journal of Applied Linguistics $\mathcal{E}$ English Literature, 6(3), 262-267.

Kementerian Pendidikan Malaysia. (2013). Malaysia Education Blueprint 20132025 (Preschool to Post-secondary Eudcation). Putrajaya, Malaysia: Pusat Pentadbiran Kerajaan Persekutuan. Retrieved from http://www.moe.gov.my/userfiles/file/PPP/Preliminary- BlueprintEng.pdf

Kirmizi, O. (2014). Measuring technology acceptance level of Turkish pre-service English teachers by using technology acceptance model. Educational Research and Reviews, 9(23), 1323-1333.

Krejcie, R. V., \& Morgan, D. W. (1970). Determining sample size for research activities. Educational And Psychological Measurement, 30(3), 607-610.

Kwok, D., \& Yang, S. (2017). Evaluating the intention to use ICT collaborative tools in a social constructivist environment. International Journal of Educational Technology in Higher Education, 14(1), 14-32.

Ling, S, E., \& Muuk, M. A. (2015). Blended learning in teaching secondary schools' English: a preparation for tertiary science education in Malaysia. Procedia- Social and Behavioral Sciences, 167(2015), 293-300.

Mack, L. (2010). The philosophical underpinnings of educational research. Retrieved from 
https://secure.apu.ac.jp/rcaps/uploads/fckeditor/publications/polygl ossia/Pol yglossia_V1 9_Lindsay.pdf

Ministry of Resource Development and IT. (2011). Sabah state ICT blueprint. Retrieved from http://www.sabah.gov.my/main/Content/info/State\%20ICT\%20Blue print $\% 2$ 0Final.pdf

Mohammed Simko Abdullah., \& Mehmet Toycan. (2018). Analysis of the Factors for the Successful E-Learning Services Adoption from Education Providers' and Students' Perspectives: A case study of Private Universities in Northern Iraq. Eurasia Journal of Mathematics, Science and Technology Education, 14(3), 1097-1109.

Ng, S. F., \& Confessore, G. J. (2011). Assessing the capacity for success in distance learning in Malaysia. Procedia - Social and Behavioral Sciences, 15, 17421750 .

Oxford, R. L., \& Burry-Stock, J. A. (1995). Assessing the use of language learning strategies worldwide with the ESL/EFL version of the Strategy Inventory for Language Learning (SILL). System, 23(1), 1-23.

Rubaai, N., \& Hashim, H. (2019). Polytechnic ESL Lecturers' Acceptance Of Using Massive Open Online Course (MOOC) For Teaching English As A Second Language (ESL). International Journal of Innovative Technology and Exploring Engineering (IJITEE), 8(9), 114-121

Rosyidah Muhammad. (2015). The development of ICT and its political impact in Malaysia. (JOBSTS) Journal of Borneo Social Transformation Studies, 1(1).

Shahroom, A. A., \& Hussin, N. (2018). Industrial Revolution 4.0 and Education, International Journal Of Academic Research In Business And Social Sciences, 8(9), 314-319.

Soleimani, E., Ismail, K., \& Mustaffa, R. (2014). The acceptance of mobile assisted language learning (MALL) among post graduate ESL students in UKM. Procedia-Social and Behavioral Sciences, 118(1), 457-462.

Taber, K. S. (2018). The use of Cronbach's alpha when developing and reporting research instruments in science education. Research in Science Education, 48(6), 1273-1296.

Tan, C. K. (2018). Exploring TESL Pre-Service Teachers ${ }^{\text {ee }}$ Technology Acceptance Perspectives towards Online Multimedia Materials Development: A Case Study in Sabah, East Malaysia. International Journal of Languages, Literature and Linguistics, 4(4), 319-323. 
Trayek, F. A., Ahmad, T. B. T., Nordin, M. S., Dwikat, M. A., Abulibdeh, E. S. A., Asmar, M., \& Sawari, S. S. M. (2016). Underlying structure of e-learning readiness among Palestinian secondary school teachers. Retrieved from https://staff.najah.edu/media/published_research/2019/01/14/Elearning_readiness_and_its_correlates_among_secondary_school_teach ers_in_Nablus_Palestine.pdf

Wong, S. L., \& Teo, T. (2009). Investigating the technology acceptance among student teachers in Malaysia: An application of the technology acceptance model (TAM). Asia-Pacific Education Researcher, 18(2), 261-272.

\section{Authors' Brief CV}

$\mathrm{Ke} \mathrm{Hu}$ is an English language teacher at School of International Business, Hunan University of Information Technology, China. His research interests are teaching English as a second language (TESL) and E-learning.

Dr. Asmaa AlSaqqaf is a senior lecturer at the TESL Program, Faculty of Psychology and Education, Universiti Malaysia Sabah (UMS), Malaysia. Her research interests include E-learning, developing research scales, teaching English as a second language (TESL). 